\title{
A fényszennyezés műszaki jellemzőire és élettani hatásaira vonatkozó, lakossági ismeretek felmérése két településen
}

\section{Survey of population knowledge on the technical characteristics and physiological effects of light pollution in two settlements}

\author{
A. Apró ${ }^{1}$, R. NovÁK ${ }^{1,2}$, M. HANKOVSZKI ${ }^{1}$, A. KerTÉSZ ${ }^{1}$, J. MiKA ${ }^{1}$ \\ 1Eszterházy Károly Egyetem, 3300 Eger, Eszterházy tér 1., apro.anna@uni-eszterhazy.hu \\ 2Bükki Nemzeti Park Igazgatóság, 3304 Eger, Sánc u. 6.
}

\begin{abstract}
Absztrakt. Iparosodott világunk egyik legújabb környezeti kihívása a fényszennyezés. Ez, egyszerüen fogalmazva, azt jelenti, hogy a szükségesnél több fényt bocsátunk ki, és ezt gyakran az emberek és az állatvilág számára zavaró, sốt az egészségre káros hullámhosszakon tesszük. E problémakör tudatosítását szolgálják az ún. Csillagos Égbolt Parkok, ahol nagy területen semmilyen mesterséges fényforrás nem terheli a környezetet. Az egyik ilyen Park BAZ megyében, Répáshuta közelében van, illetve élvez folyamatos fejlesztést.

Tanulmányunk arról a kérdőíves vizsgálatról számol be, amit a témakörben tájékoztatást élvező Répáshuta illetve a hozzá közel fekvố, de a problémakörról közvetlen ismereteket nem kapó Cserépváralja településeken végeztünk. Mindkét község lakosságának a száma 400 körül van, akik közül 30 lakost kérdeztünk meg, gondosan ügyelve arra, hogy mindenki más-más családban éljen. Közvetlen helyszíni lekérdezéssel 21-21 kérdésre kértünk és minden esetben kaptunk is válaszokat, természetesen ügyelve a válaszadók teljes anonimitására. A felvételezésre 2019 márciusában és áprilisában került sor.
\end{abstract}

Abstract. One of the newest environmental challenges in our industrialized world is light pollution. It means that we emit more light than necessary, and this is often done at wavelengths that are both disturbing and even harmful to human health. The Dark Sky Parks, where over a large area there are no artificial light sources that burden the environment. One of these parks is located in BAZ County, near Répáshuta, and is under continuous development. Our study reports on a questionnaire survey conducted in Répáshuta, which is informed about light pollution, and in Cserépváralja settlements close to it, but without direct knowledge of the problem. The population of both villages is around 400. With a direct on-site survey, we asked 21-21 questions to 30-30 person and received answers in all cases, of course, taking full account of the anonymity of the respondents. Recruitment took place in March and April 2019. 


\section{A fényszennyezés, mint környezeti probléma}

A környezetet erő éjszakai mesterséges fény hatásaival a kutatók az elmúlt pár évtizedben kezdtek hangsúlyosabban foglalkozni. A fényszennyezés „olyan mesterséges zavaró fény, ami a horizont fölé vagy nem kizárólag a megvilágítandó felületre és annak irányába, illetve nem a megfelelő időszakban világít, ezzel káprázást, az égbolt mesterséges fénylését vagy káros élettani és környezeti hatást okoz, beleértve az élővilágra gyakorolt negatív hatásokat is - olvashatjuk az OTÉK meghatározása szerint.

Az ökológiai rendszerek tekintetében a fényszennyezés negatív hatása a növények, rovarok, madarak életében, az emberi szervezet esetében pedig a melatonin hormon csökkentett termelődésében jelentkezik. A melatonin hormon komoly szerepet játszik a test működésének szabályozásában. Hatással van a testhőmérséklet szabályozására, és erős antioxidánsként van jelen (LELKES, 2013).

A madarak esetében három hatás figyelhető meg:

- költő- vagy telelőterület választás: minél távolabb a kivilágított létesítményektől.

- vándorlás: a tájékozódás megzavarásában mutatkozik meg a fényszennyezés negatív hatása, ez pedig a tervezett leszállási területtől eltérő helyszínhez, vagy a fényárban úszó épületeknek való nekiütközéshez vezethet.

- bioritmus: azokon a területeken, ahol a mesterséges megvilágítás elkerülése nem lehetséges a madaraknak, felborul a bioritmusuk. A nappali életmódot folytató fajok éjszaka is aktívan tevékenykednek.

A rovarvilágban a fényszennyezés az alábbi káros hatásokat fejtheti ki:

- az élőhelyeiktől, táplálkozóhelyeiktől való elcsalogatás;

- $\quad$ szaporodó partnerek szeparálása;

- nagyobb kitettség a ragadozóknak;

- $\quad$ az egyedek közvetlen vagy közvetett elhullása;

- lokális kipusztulás, a populáció összeomlása (KOLLÁTH -GYARMATHY, 2015).

A természetes táj esetében a csillagos égbolt vizsgálatának nehézségeibe ütköztek csillagászaink, melynek következtében felmerült a kérdés, hogy a mai emberek életében nem fog jelentős szerepet játszani a csillagos égbolt, mint például a Tejút látványa. A fenti káros folyamatok megfékezése érdekében a Nemzetközi Sötét Égbolt Társaság (International Dark Sky Association) kezdeményezésére új program indult útjára. Ennek lényege, hogy világszerte csillagoségbolt parkokat hoznak létre olyan térségekben, ahol megőrizhetők a természetes adottságok a fényszennyezés elenyésző jelenlétéből következően. Hazánk a Zselicben, a Hortobágyi és Bükki Nemzeti Park, többek között Répáshuta település területén található csillagoségbolt parkokkal büszkélkedhet. A parkok gazdag programkínálattal várják az érdeklődőket csillagászati és természeti kiállításokkal, vezetett éjszakai túrákkal, továbbá aktív szerepet vállalnak a lakosság informálásában a fényszennyezés tükrében. 


\section{A lakossági felmérés}

Tanulmányunk a Répáshuta és Cserépváralja településen végzett a kérdőíves vizsgálat eredményeit ismerteti. Répáshuta teljes közvilágítása egy új világítási rendszer működési elvén alapszik, melyen keresztül csökken az energiafogyasztás, valamint az élővilág és emberi egészség megőrzésében is pozitív változást eredményez, emellett jelentősen csökken a fényszennyezés mértéke. A beruházás kezdetekor a lakosság egy fórum keretein belül ismereteket szerzett a témakörben. A vizsgálatba bevont kontroll település hasonló lakosságszámmal rendelkezik, azonban közvetlen ismereteket nem kaptak a felmerülő problémakörről.

A két település lakossága az 1. táblázatban foglaltak szerint meghaladja a 400 fót, így reálisnak tekinthetjük az egy-egy településről beérkezett 30 választ. Súlyt fektettünk viszont az életkorok szerinti sajátosságok megismerésére. Törekedtünk az 5 korcsoport (19-30, 31-40, 41-50, 51-60 és 60 fölött) mindegyikéből egyforma számú válaszadót találni.

\begin{tabular}{|l|c|c|c|c|c|}
\hline \multicolumn{3}{|c|}{ Cél-település } & \multicolumn{3}{c|}{ Kontroll-település } \\
\hline \multirow{2}{*}{ Település } & Járás & $\begin{array}{c}\text { Lakos fő / nép- } \\
\text { sűrűség } \\
\text { fő/km2 }\end{array}$ & Település & Járás & $\begin{array}{c}\text { Lakos fő / nép- } \\
\text { sűrűség fő/km2 }\end{array}$ \\
\hline Répáshuta & Miskolci & $441 / 26$ & Cserépváralja & Mezőkövesdi & $410 / 28$ \\
\hline
\end{tabular}

1. táblázat A vizsgált települések becsült népessége és népsứrüsége a 2019-es adatok szerint Forrás: $\underline{\text { http://nepesseg.com/ saját szerkesztés }}$

A kérdőívben feleletválasztós, nyílt- és zárt végű kérdések megválaszolását kértük. A nyílt kérdésekre rövid, egyértelmű válaszokat vártunk, emellett a zárt, feleletválasztást igénylő kérdésekben, rangsorolást igénylő és intenzitáskérdések megadására került sor.

A kérdések 5 fő csoportba sorolhatók: (i) a világítás hatásairól tanúskodó ismeretek; ahol a különböző lámpatípusok felismerését követően a kitöltők nyilatkoztak az éjszakai világítás hatásáról emberi szervezet egészségére, illetve az állatvilág számára zavaró hatásaira vonatkozóan. A (ii) csoportban a világítási szokásokra otthon, iskolában/munkahelyen, közterületen kérdeztünk rá. Az éjszakai nyugodt és pihentető alvást a teljes sötétségbe burkolózó hálószobában érhetjük el. A pihentető alvás minőségét befolyásolja a közterületről beszűrődő fény és a használatban levő elektronikus eszközök. Erre vonatkozóan vártunk válaszokat a (iii) „mi fárasztja, stresszeli az embereket saját életükben” kérdéscsoportban. A következőkben (iv) a kitöltő és a csillagos égbolt kapcsolatára voltunk kíváncsiak, ahol arról nyilatkoztak a megkérdezettek, hogy gyönyörködnek-e, vizsgálódnak-e egyáltalán a csillagos égbolton, kiegészítve azzal, hogy mely égi objektumokat ismerik fel. Az utolsó kérdéscsoportban (v) további csillagászati, egyéb energiatakarékossággal kapcsolatos ismeretek kerültek a középpontba, ezek közül pedig kiemelkedő kérdésként szerepelt, hogy hallott-e már a fényszennyezés problémaköréről, illetve ha igen, akkor milyen forrásból értesült róla. 


\section{Eredmények}

Terjedelmi okokból témakörönként csak 1-2 kérdésre adott válaszokat tudunk elemezni.

\subsection{A világítás hatásairól tanúskodó ismeretek}

$\mathrm{Az}$ 1. ábra két részében a fényszennyezésnek az emberre, illetve az állatokra gyakorolt hatásával kapcsolatos válaszokat értékeljük. Érdekesség, hogy a témakörben jártasabbnak gondolt répáshutaiak csaknem egynegyede mutatkozott bizonytalannak az emberre gyakorolt hatást illetően, míg egyharmaduk szerint nincs is ilyen hatás. A kontroll településen is hasonló e két kategória összege, de ezen belül a hatást tagadók aránya 40\%. Azok között, akik szerint van valamilyen hatás az emberre, Répáshután sokkal inkább erős hatást tulajdonítanak a fényszennyezésnek, míg a kontroll településen inkább csak az alvás megzavarását tartják valós hatásnak.
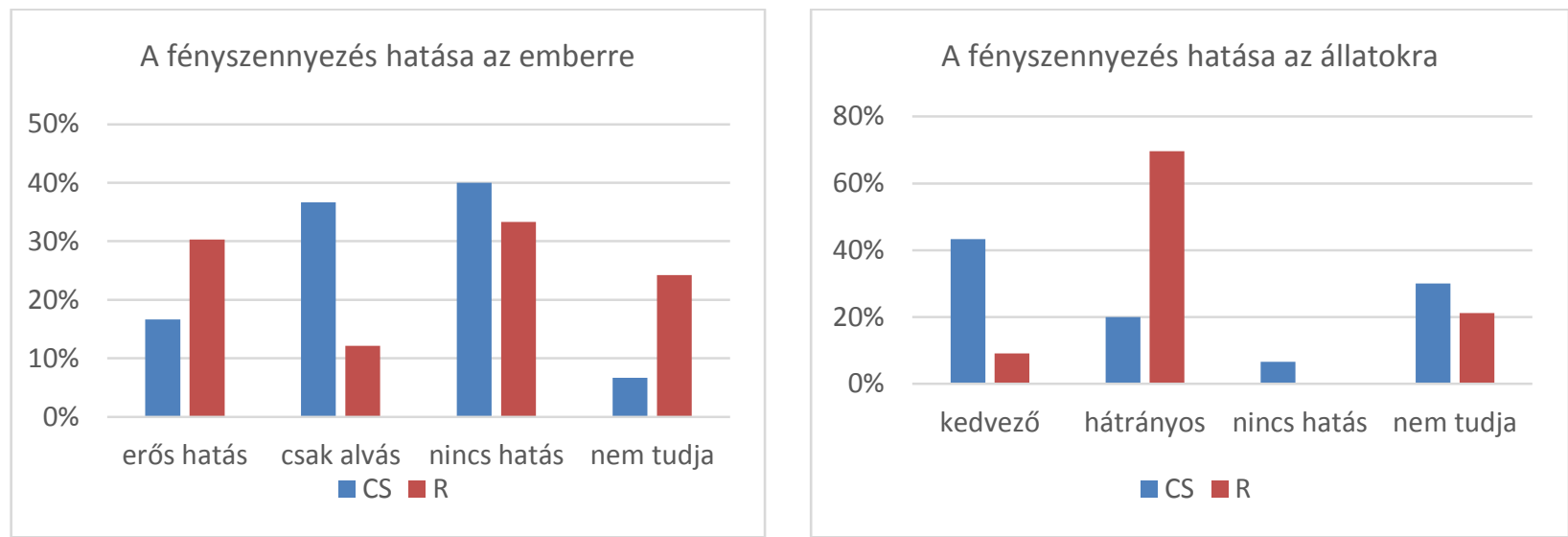

1. ábra A fényszennyezés hatása (a) az emberre és (b) az állatokra a cserépváraljai (CS) és a répáshutai (R) lakossági felmérés alapján.

Az állatokra gyakorolt hatást Répáshután senki nem tagadja és alacsonyabb a bizonytalanok aránya is, mint a kontroll településen. A megkérdezettek csaknem 70\%-a kedvezőtlennek tartja a fényszennyezés hatásait az állatokra, s csupán néhány százalék véli azt kedvezőnek.

\subsection{Világítási szokások otthon, iskolában/munkahelyen, közterületen}

Az otthoni világítás fajtáinak gyakoriságát és a közvilágítás lakossági megítélését tükrözi a 2. ábra két része. Mindkét településen a hagyományos izzók és a LED világítás a leggyakoribb. Répáshután egyforma, 70\% fölötti gyakoriságú ez a két típus, míg Cserépváralján majdnem minden háztartásban van még hagyományos izzó és a LED-ek aránya alig több, mint 40\%. A halogénlámpák és a kompakt fénycsövek aránya 10-20\%. Megjegyezzük, hogy az első csoportban feltett kérdésre, ami a világítási eszközök felismerését tesztelte, Répáshután a jó válaszok aránya 91\% volt, míg a kontroll településen csupán $50 \%$ ! 

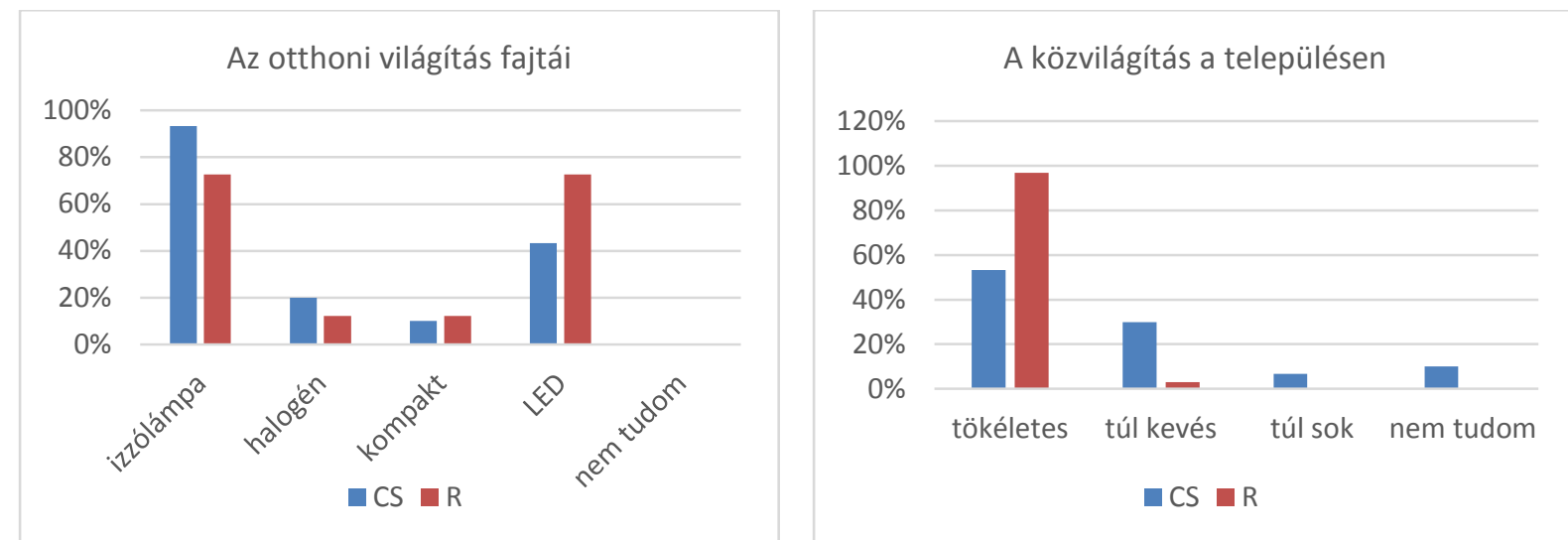

2. ábra (a) az otthoni világitás fajtáinak megoszlása és (b) a települési közvilágitás megitélése a cserépváraljai (CS) és a répáshutai $(R)$ lakossági felmérés alapján.

A répáshutaiak csaknem 100\%-a teljesen elégedett a nemrég megújított, sárga fényű közvilágítással. Bár a kontroll településre ugyanez nem teljesül, a válaszadók több mint fele itt is elégedett. Túl kevés fényre 30\% panaszkodik, míg túl soknak alig pár százalék tartja azt.

\subsection{Ami fárasztja, stresszeli az embereket saját életükben}

Ehhez a ponthoz az a 3. ábrán bemutatott kérdés tartozik, amellyel felmérhető, hogy miként értékelik a lakosok az ablakon keresztül beérkező sok utcai fényt. Várakozásunkkal ellentétben, bőven $80 \%$ fölött volt azok aránya, akik nem tartják ezt birtokháborításnak.

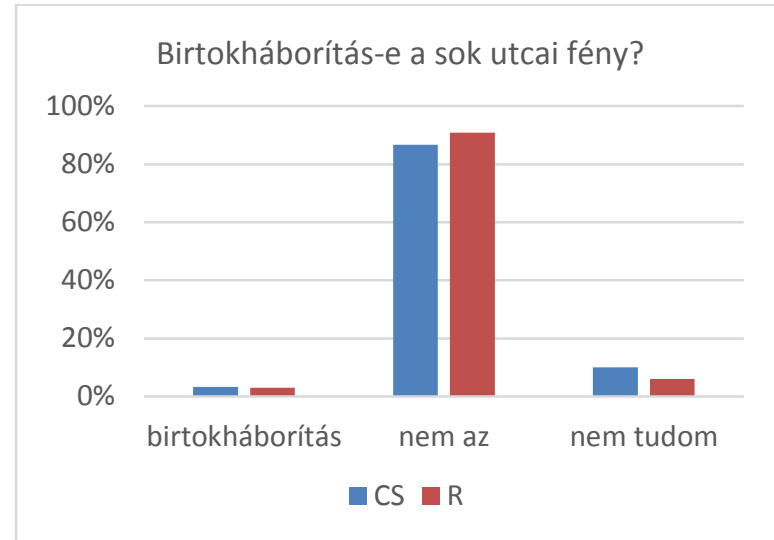

3. ábra Birtokháborításnak tartja-e az ablakon bejövő erös utcai fényt? Cs. - Cserépváralja, $R$ Répáshuta.

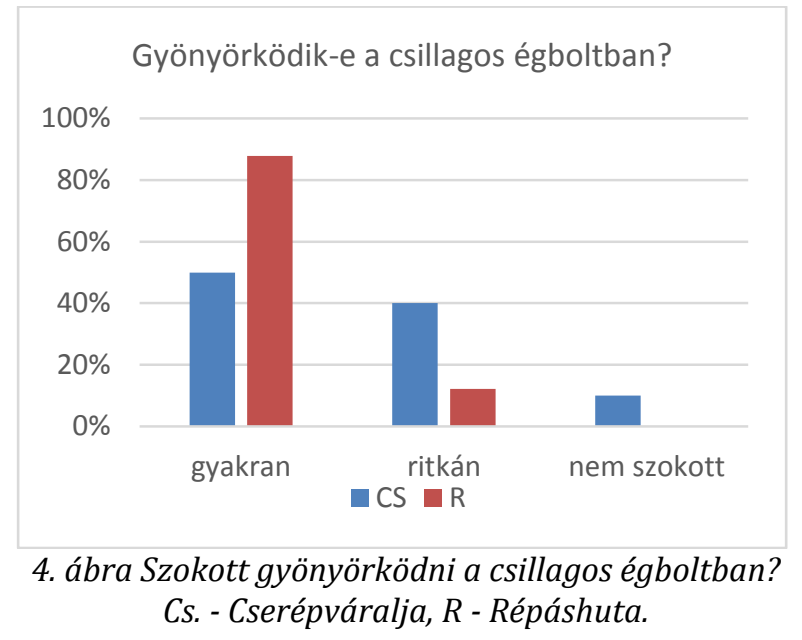

\subsection{A kitöltők kapcsolata a csillagos égbolttal}

A fenti, 4. ábra már azt taglalja, hogy kinek, mekkora veszteséget jelent, ha a fényszennyezés miatt ritkábban jut a csillagos égbolt élményéhez. Répáshután a válaszadók csaknem 90\%-a gyakran gyönyörködik és szemlélődik a csillagos égbolton, míg a többiek ritkán. A kontroll település válaszadóinak 50\%-a gyakran, míg 40\%-a ritkán szemlélődik a csillagos égbolton. Répáshután senki nincs, aki sosem élvezi azt és cserépváralján is csupán a válaszadók 10 \%-a. 


\subsection{Energia-takarékossággal kapcsolatos ismeretek}

Az energia-takarékossággal és a fényszennyezéssel kapcsolatos kérdésekből látunk kettőt az 5 ábrán, amely továbbá szemlélteti a kérdésekre adott lakossági válaszok arányait is. A vizsgált négy fogalom mindegyikét többen ismerik Répáshután, mint Cserépváralján. Különösen a „fényszennyezés” és a „fényáram” terén nagy az (önbevalláson alapuló) eltérés. A két település között nagy különbség mutatkozik a fényszennyezés terén fennálló értesültség terén is, ami minden kategóriában néhányszorosan felülmúlja a kontroll településen bevallott tájékozottságot. Répáshután a legtöbb ismeret az Internetről származik.
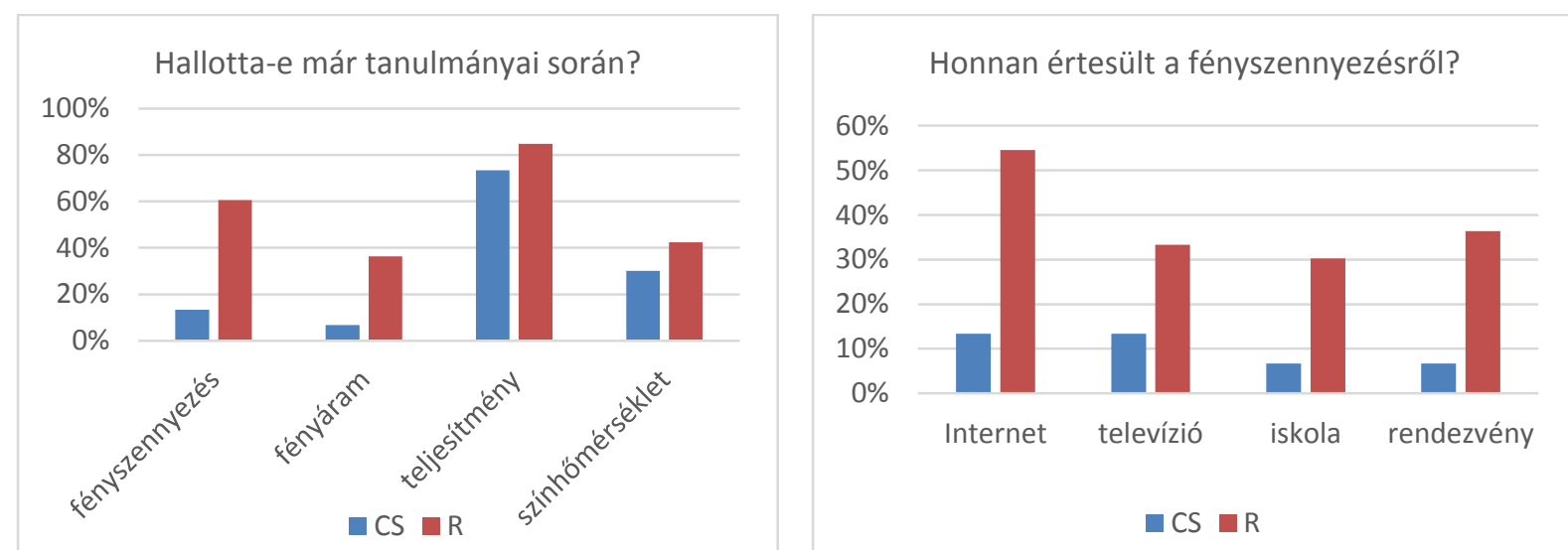

5. ábra (a) Annak aránya, akik hallották már a felsorolt világitási fogalmakat és (b) a fényszennyezésröl történt értesülés forrásai a cserépváraljai (CS) és a répáshutai (R) lakossági felmérés alapján.

\section{Következtetések}

A bemutatott, első vizsgálatok arra utalnak, hogy a répáshutai válaszadók többnyire tájékozottabbak, és jobban látják a problémákat, ám az is kiderült, hogy a két településen erősen eltért a válaszadók életkor és az iskolázottság szerinti megoszlása. Ezért, jelenleg dolgozunk az e két szempont hatását semlegesítő rétegzett mintavételen annak érdekében, hogy a megmaradó tudásbeli különbség már valóban a két település irányában kifejtett tájékoztatás hatásának legyen betudható.

\section{Köszönetnyilvánítás}

A fényszennyezéssel kapcsolatos kutatásokat támogatta az EFOP-3.6.2-16-2017-00014 "Nemzetközi kutatási környezet kialakítása a fényszennyezés vizsgálatának területén" elnevezésű pályázat.

\section{Hivatkozások}

[1] CsÖRGITS GÁBOR. - GYARMATHY István. (2006): A fényszennyezés természetvédelmi-ökológiai aspektusai, Elektrotechnika, 99/9. pp. 22-24.

[2] Kolláth Z.-Gyarmathy I. (2015): Fényszennyezés és természet, Természetbúvár, 70. 4. PP.4-7.

[3] LELKES ZoLTÁN (2013): A fény hatása a napszaki ritmusra és az alvásra. In: Világítástechnikai évkönyv, Világítástechnikai Társaság, Budapest, pp. 108-110. 
International Journal of Engineering and Management Sciences (IJEMS) Vol. 4. (2019). No. 4

DOI: 10.21791/IJEMS.2019.4.17.

[4] OTÉK: 253/1997. (XII. 20.) Korm. rendelet az országos településrendezési és építési követelményekröl. $\quad$ https://net.jogtar.hu/jr/gen/hjegy_doc.cgi?docid=99700253.KOR\#lbj182id51f (utolsó letöltés: 2019.10.13.) 